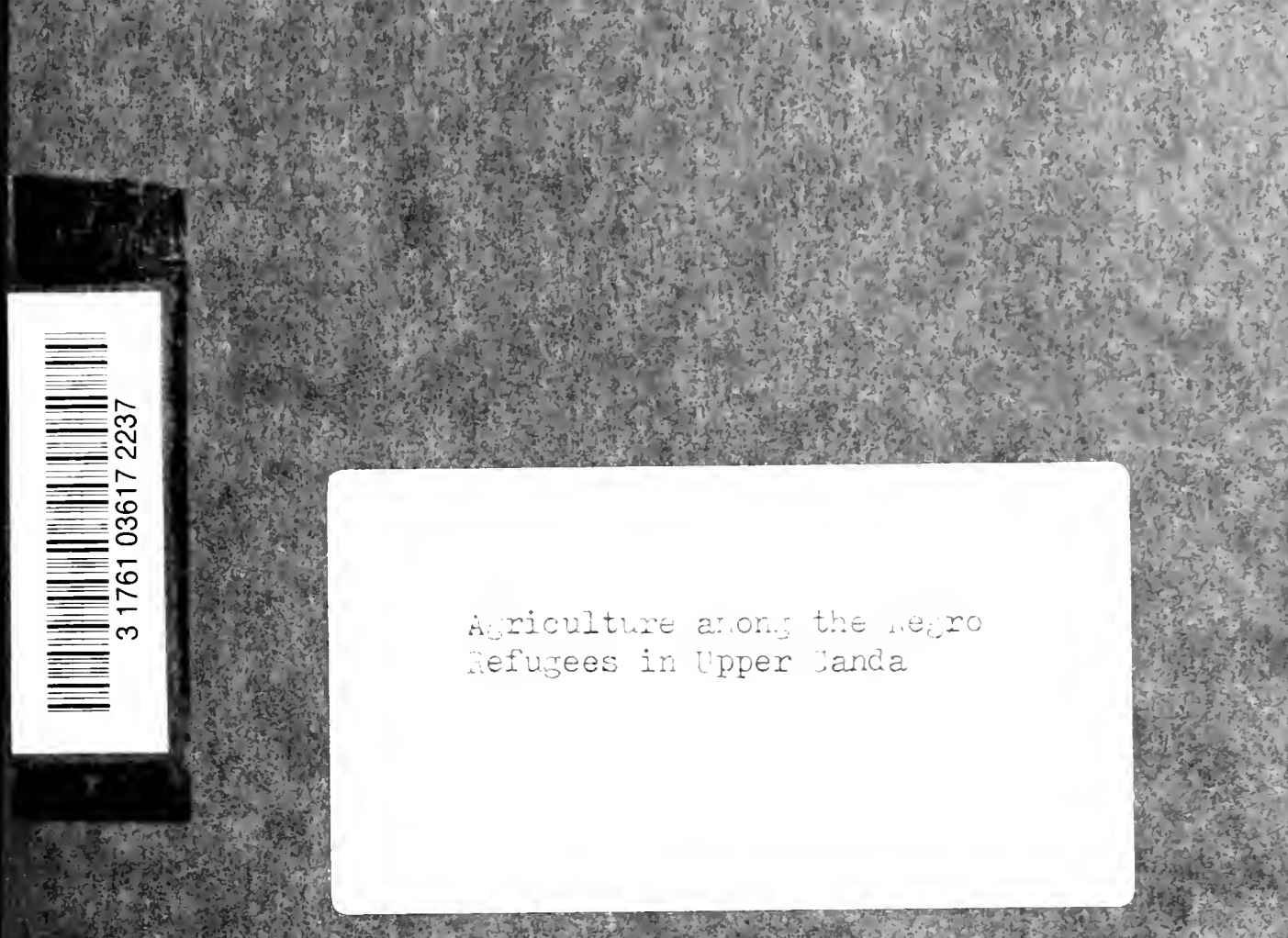

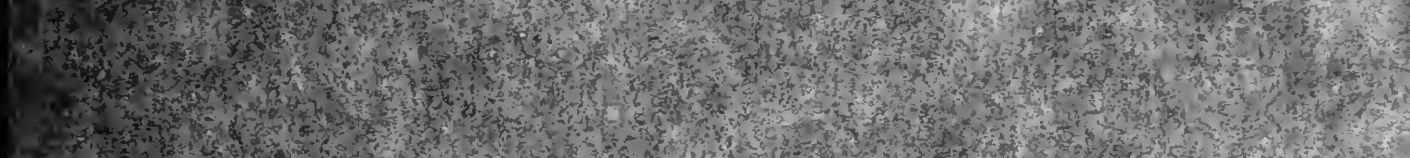
- wit to

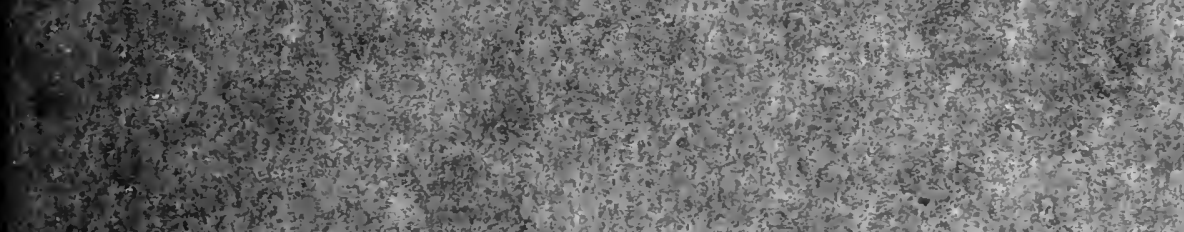
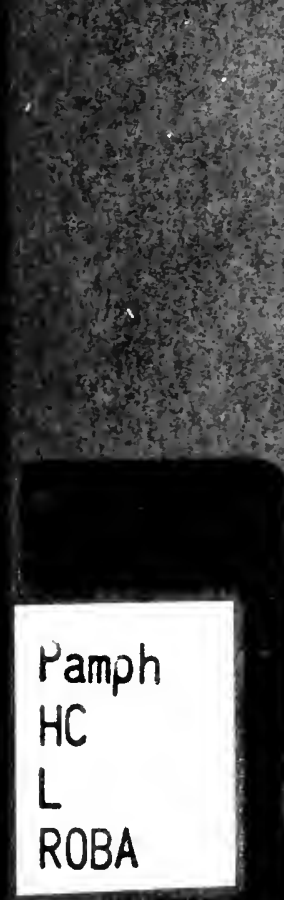
Digitized by the Internet Archive in 2010 



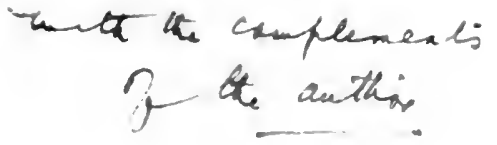

Reprinted from the Journal of NeGro History, Vol. XXI, July, 1936, No. 3

\section{AGRICULTURE AMONG THE NEGRO REFUGEES IN UPPER CANADA}

The bulk of the Negroes who came into the province of Upper Canada (now Ontario) in the period before the Civil War had a background of agriculture; and it was quite natural, therefore, that in their new environment they would tend to turn to the land as a source of livelihood. In this tendency they were encouraged by the government of the province and by their own leaders. Though the Negro immigration was neither sufficiently large nor sufficiently permanent to affect in any marked way the agriculture of the province, it did demonstrate rather forcibly that the Negro, when given opportunity and freedom, was not inferior to some other races in his ability to improve his condition. When, in the last year of the Civil War, Dr. Samuel G. Howe visited Canada as a representative of the Freedmen's Inquiry Commission to investigate the economic and social conditions of the Negroes there resident, he was much impressed by this fact and commented upon it at some length in his report.

Negroes were to be found in Upper Canada from the very beginnings of the province. There were even some Negroes held in slavery during the first quarter century, although in the second session of the Legislative Assembly a bill had been introduced and unanimously. passed which prohibited the bringing in of any more slaves and made provision for the gradual extinction of such slavery as then existed. Upper Canada occupies the honorable position of having been the first British colony to abolish slavery. At a very early date, therefore, a tradition of freedom was created which revealed itself conspicuously when, at a later date, the province became a refuge for

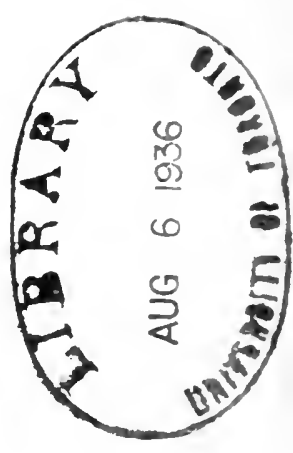




\section{Agriculture Among the Negro Refugees}

runaway slaves and for those whose freedom was endangered by the Fugitive Slave Law.

Dr. Howe, in the course of his inquiry into the condition of the refugees in Upper Canada, gave attention to the Negroes in the towns and cities rather than to those in the country districts. At that particular time (1864) there was a considerable Negro population in the towns in the western part of the province and indications of race prejudice were occasionally in evidence, particularly with respect to the presence of Negro children in the common schools. Social questions of this kind bulk large in the Howe report, possibly because they were conditions with which the investigator was himself familiar; nevertheless, he makes quite definite observations on the Negro farmers whom he encountered. He concluded that, in general, the Negro farmers were probably better off than were those of the race who were living in the towns. He found them generally owning the land which they occupied, having in many cases paid off mortgages and having a clear fee. From the standpoint of cleanliness and comfort he found the Negro farmhouses differing in no respect from those of neighboring white settlers, and he found many evidences of distinct progress shown in permanent dwellings and barns, enclosed fields and livestock.

Besides visiting and interviewing individual farmers Dr. Howe inspected the Buxton settlement in Kent county which had been founded in 1848 by Rev. William King, a Scottish Presbyterian clergyman. Of Buxton colony Dr. Howe wrote:

"Buxton is certainly a very interesting place. Sixteen years ago it was a wilderness. Now, good highways are laid out in all directions through the forest; and by their side, standing back thirty-three feet from the road, are about two hundred cottages, all built on the same pattern, all looking neat and comfortable. Around each one is a cleared space, of several acres, which is well cultivated. The fences are in good order; the barns are well filled; and eattle, and horses, and pigs, and poul- 


\section{Journal of Negro History}

try, abound. There are signs of industry, and thrift, and comfort, everywhere; signs of intemperance, of idleness, of want, nowhere. There is no tavern, and no groggery; but there is a chapel and school house.

"Most interesting of all are the inhabitants. Twenty years ago, most of them were slaves, who owned nothing, not even their children. Now they own themselves; they own their houses and farms; and they have their wives and children about them. They are enfranchised citizens of a government which protects their rights."

The Buxton settlement, or Elgin Association as it was legally known, had received a charter from the Parliament of Canada in 1850 empowering it to acquire and hold lands in Kent county and to sell these lands to the colored settlers. The success that attended the venture was largely due to Rev. Mr. King. Born in Scotland, he had lived for a time in Louisiana and by marriage and the subsequent death of his wife found himself the owner of fifteen slaves. Being averse to selling them, he determined to take them to Canada and to establish there a colony to which others of their race might also come. He received the support of the Synod of the Presbyterian Church of Canada, this body assisting in bringing the plan to the attention of the government and in securing the legislation relating to the land grant of 9,000 acres.

By 1852 there were 75 colored families at Buxton, a total population of about 400 , with 350 acres of land cleared and more than 200 acres under cultivation. A year later, the fourth annual report showed 130 families, numbering 520 persons, having 500 acres of land cleared, 135 acres partially cleared, and 415 acres under cultivation. The colony then possessed 128 cattle, 15 horses, 30 sheep and 250 hogs.

The annual report for 1854 recorded yet further advance. Cleared land totalled 726 acres, with 174 acres partially cleared and 577 acres under cultivation. A year

2 The refugees from slavery in Canada West. Report to the Freedmen's Inquiry Commission, by S. G. Howe, Boston, 1864. Pp. 70-71. 


\section{Agriculture Among the Negro Refugees}

later there was 827 acres of cleared and fenced land with 216 acres chopped and ready to go under the plough in 1856. Livestock in 1855 consisted of 190 cattle and oxen, 40 horses, 38 sheep and about 600 hogs. In this year a saw-mill and a grist-mill were put in operation. It was estimated that at this time there was standing timber on the colony lands worth more than $\$ 125,000$.

The New York Tribune sent a reporter to Buxton in 1857, when the colony was seven years old. He estimated the population at about 800 . Nore than 1,000 acres of land had then been cleared, while on 200 acres more the trees had been felled and the land would go under cultivation in the following year. The acreage under cultivation in 1857 was reported to be as follows: wheat, 200 acres; oats, 70 acres; potatoes, 80 acres; other crops, 120 acres. The livestock consisted of 200 cattle, 80 oxen, 300 hogs, 52 horses and a small number of sheep.

At the close of the Civil War there was a desire on the part of some of the Buxton colonists to return to their former homes in the South, though in this they received no encouragement from Washington when their plans became known. By 1873 the directors of the Elgin Association, feeling that their work had been accomplished, wound up its affairs. Every man who had entered the colony had had it firmly impressed upon him that independence and ownership of property was to be his goal and a large number had achieved that condition. Buxton remains to this day the most distinctly Negro community in all Canada. ${ }^{2}$

Wilberforce, a settlement, about twenty miles north of the present city of London, Ontario, was an earlier attempt at colonization. About the year 1829 enforcement of the Black Laws of Ohio drove out a considerable number of

\footnotetext{
${ }^{2}$ For a history of the Buxton settlement see Annie Straith Jamieson, William King, Friend and Champion of Slaves, Toronto, 1925. Mrs. Jamieson, who is a niece of Rev. William King, has deposited his papers in the Public Archives at Ottawa.
} 
Negroes from the city of Cincinnati. Of those who came to Canada, a part settled at Wilberforce. Benjamin Lundy, the early abolitionist, visited the place in 1832 during the course of his journey through the province from the $\mathrm{Ni}$ agara to the Detroit Rivers. In his account of the settlement he wrote:

"They have purchased nearly 2,000 acres in the whole, 200 of which are cleared and about 60 sown with wheat. The settlers have cut a wide road through seven miles and a quarter of very thickly and heavily timbered land for the Canada Companythe price for which was placed to their credit in the purchase of their several lots. It should be remarked that in clearing they leave no trees deadened and standing, as it is customary with many in new settlements; but cut all off, though the labor is great. They have about 100 head of cattle and swine, and a few horses. Oxen are mostly used with them for hauling, ploughing, etc. They have a good substantial sawmill erected on a branch of the Au Sable, within the precincts of their settlement, and, of course, they will have no difficulty in procuring lumber for building." 3

Wilberforce was no such success as Buxton, partly because of faulty management of its financial affairs and partly through the racial hostility of incoming Irish settlers towards the presence of a body of Negroes. The most complete account of the experiment is found in the narrative of Austin Steward, ${ }^{4}$ a member of the colony.

There are numerous references to this settlement in the Canadian travel literature of the 'thirties and 'forties. Patrick Shirreff, who passed through in 1834, said of it:

"On the boundary of the Huron tract, next to the London district, we passed a Negro settlement. The houses of the coloured people seemed of a particular construction, having the chimney stack on the outside of the log-house, and which stack

${ }^{8}$ The Diary of Benjamin Lundy written during his journey through Upper Canada, January, 1832. Reprinted from the Genius of Universal Emancipation of Mareh, April, May, 1832, in Ontario Historical Society, Papers and Records, Vol. XIX (1922), pp. 110-133.

'Austin Steward, Tuenty-tu' Years a Slave and Forty Fears a Freeman, Embracing a Correspondence of Several Years While President of Wilberforce Colony, London, Canada West. Rochester, N. Y., 1859. 


\section{Agriculture Among the Negro Refugees}

is composed of thin sawn timber, placed horizontally, and mixed with clay. Their chief crop was Indian corn, well cultivated. Before my departure from Britain I had heard of this settlement instanced as a complete failure, and used as an argument against the emancipation of slaves, then a general topic of conversation. The houses, barns, fences and general appearance are certainly mean enough, but I considered it in most respects equal and in some superior to settlements of whites in the Huron tract of the same standing of three years." 5

When the Fugitive Slave Act became effective in the fall of 1850 thousands of Negroes who had been living in the Northern States realized that their situation was dangerous and a large number moved over into Canada. The movement was particularly marked along the Detroit River, towns like Windsor, Amherstburg and Chatham finding their colored population suddenly increased. With winter coming on, the situation called for immediate action to meet the calls for relief. By the spring of 1851 it was clearly shown that organization was necessary and at a meeting held in the City Hall of Detroit on May 21, 1851, the Refugee Home Society was founded. The aims of the Society were to purchase land in Canada and to settle the Negro refugees on small plots which they would be permitted to purchase on very liberal terms.

In the working out of their plans the Society found an able helper in a Windsor Negro, Henry Bibb, who, at the beginning of 1850, had founded a little weekly paper, The Voice of the Fugitive, to set forth the needs and to champion the cause of his people. ${ }^{6}$ Bibb had probably as much part as anyone in the founding of the Refugee Home Society which he had advocated in the columns of his paper for weeks before the Detroit meeting. No official records of the Society appear to have survived, but here and there

B Patrick Sherreff, A Tour Through North America; together with a view of the Canadas and United States as adapted for agrioultural emigration. Edinburgh, 1835. P. 178.

- Files of this paper are in the Library of the University of Michigan and in the Burton Library, Detroit. 
one may come upon notices of its activities. The second annual report of the Anti-Slavery Society of Canada (1853) stated that at that time the Refugee Home Society had purchased 1328 acres of land, of which 600 acres had been taken up by settlers. As the plots were to be 25 acres to a family, this would mean 24 families. When Benjamin Drew visited Canada a year later he found that the Society had nearly 2,000 acres of land, of which half had been taken up. It was to this colony that Mrs. Laura S. Haviland came as a teacher. In her autobiography she says that the colonists raised corn, potatoes and other vegetables as well as some wheat. Rev. W. M. Mitchell, who was a missionary among his own people, makes the following reference to the colony in his "Underground Railroad":

"About ten miles from Windsor there is a settlement of 5,000 acres which extends over a part of Essex county. It is called the Fugitives' Home. Several years ago a very enterprising and intelligent fugitive slave ... bought land from the government, divided it into 20 acre plots and sold it to other fugitives, giving them five to ten years for payments. Emigrants settled here in such large numbers that it is called the Fugitives' Home. The larger portion of the land is still uncultivated, a great deal is highly cultivated and many are doing well."

Bibb, in his paper, continually emphasized the importance of placing the Negroes on the land and keeping them engaged in agriculture rather than permitting them to drift in the casual and seasonal labor in the towns. He, himself, in the spring of 1851, went about the western end of the province addressing gatherings of his people on agriculture. The Detroit market offered special opportunity to those who were near the river to dispose of their farm produce. In The Voice of the Fugitive for June 2, 1851, Bibb says:

"We saw a colored friend of ours today cross on the ferryboat with about 200 dozen of eggs, six or eight turkeys, with chickens and butter also, and they are continually going over with loads of a like character." 


\section{Agriculture Among the Negro Refugees}

In the mild climate of the Detroit River region early vegetables could be grown in abundance, and Bibb speaks of seeing sweet potatoes brought to market by the Negro farmers. Tobaceo was also grown in quantity.

Apart from the organized colonies such as Buxton and the Refugee Home settlement there were other groups of Negro farmers settled in communities throughout the province without any official organization. Rev. Hiram Wilson, who was a missionary to Negroes at St. Catharines in the Niagara district, wrote in Bibb's paper on December 3, 1851, describing a visit which he had made to a Negro settlement near Caruga in Haldimand county. At a distance of a mile from the Grand River he found about a score of families, and two miles distant a smaller group, making in all about 24 families. They had individual farms of from 50 to 150 acres, aggregating about 2,000 acres. Comfortable log cabins were set down in clearings of 20 to 30 acres. The land had been bought from the government at $\$ 3.50$ an acre, deeds to be given when full parment was made. The land was described as generally level or slightly undulating, the soil being a dark loam and the timber being of considerable value. Mr. Wilson described the Negro farmers as contented and cheerful. The adults were almost all of them ex-slaves, though one free Negro was said to have purchased his wife and children, paying $\$ 1,000$ for them.

Henry Bibb sent a communication to a convention of colored people held in Cincinnati in 1852 in which he stated that wild lands were to be had in the vicinity of Windsor and within five miles of the Detroit River at from $\$ 3$ to $\$ 5$ an acre. ${ }^{7}$ This district, he said, produced from 25 to 40 bushels of wheat an acre, and any crops that did well on Ohio soil flourished equally in this part of Upper Canada. He added:

'Reprinted in The Voice of the Fugitive, January 1, 1852. 


\section{Jouryal of Negro History}

There is no difficulty in selling any kind of produce that the farmers can produce, and that without travelling over a distance of ten miles with it. Corn is worth 50 cents per bushel, wheat 65 , oats 31 , potatoes 50 , butter 15 , lard 10 , pork, $\$ 4.50$, beef $\$ 3.50$, eggs 20 cents per dozen and chickens $\$ 1.50$ per dozen the year round. The farmer who cannot live in Canada West, with rich and fertile soil beneath his feet, with a mild climate and an anti-slavery government over his head, possessing commercial advantages inferior to none in North America, must be a little too lazy to work and would die a pauper should he be placed in a country flowing with milk and honey."

Of the Negro farmers in Canada before 1865 it may be said that they succeeded about as well as the average immigrant from other countries who came without capital. Their slavery background often affected them adversely in the earlier period of their residence in Canada, and some suffered from the more severe climate. They came to Canada, for the most part, during a state of emergency, and many thought of their stay in Canada as merely a phase which would end with a change of domestic policy in the United States. After the Civil War there was considerable migration from Canada back to the United States, but the numerous black faces still to be encountered in southwestern Ontario bear evidence to the fact that many remained in the land which had given them protection.

University of Western Ontario,

Fred Laxdon London, Canada. : 




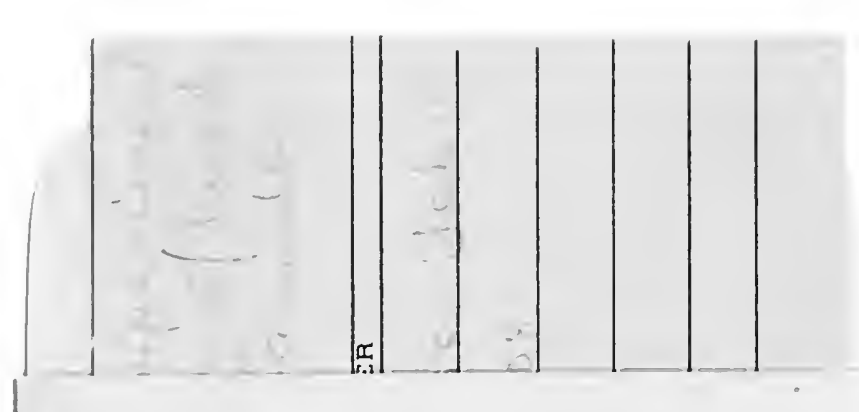


3
3 (1)

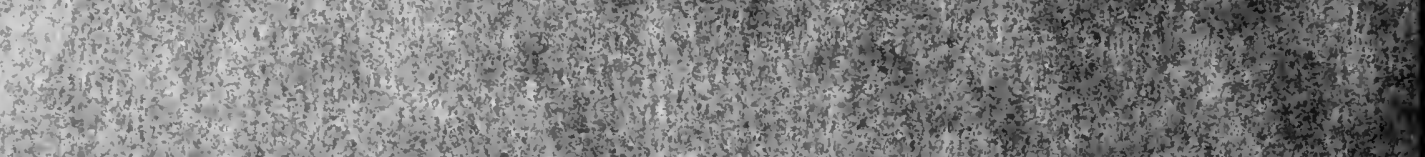

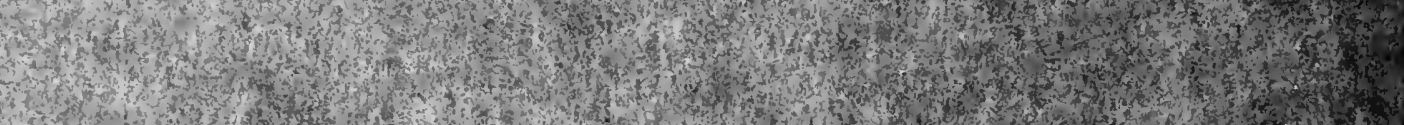

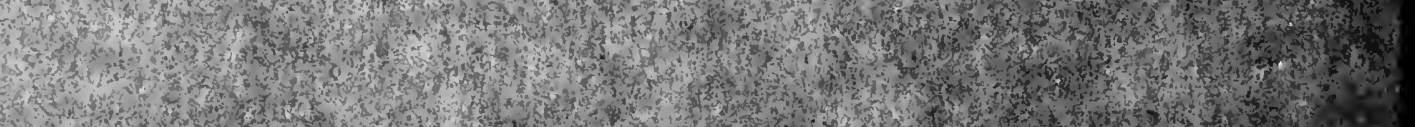

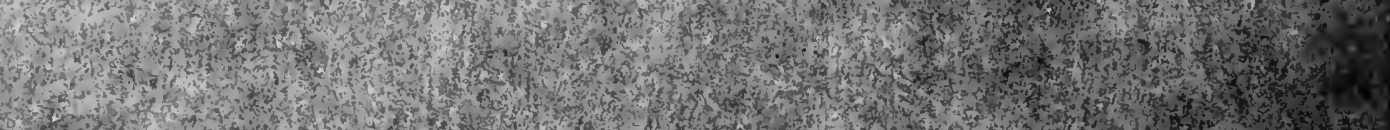

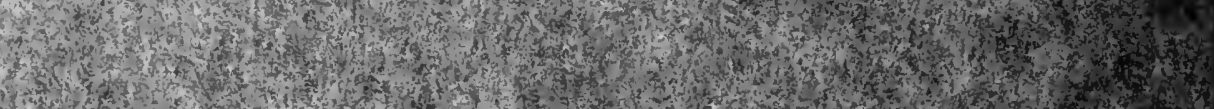
$\begin{array}{lll}1 & 1\end{array}$ 31
3 14
$H$ (x)

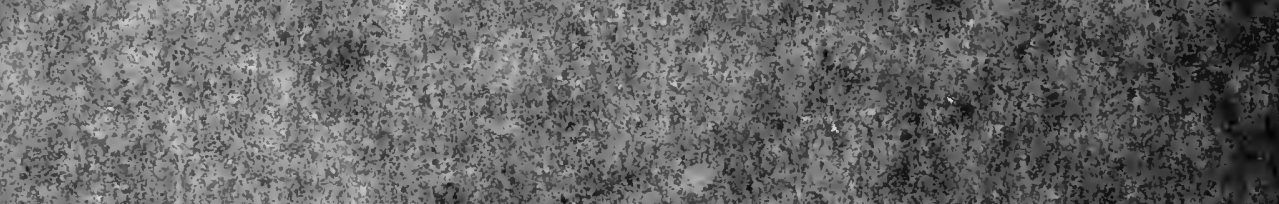

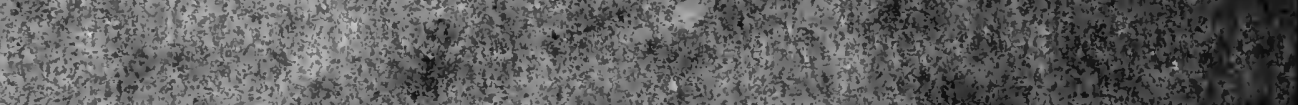

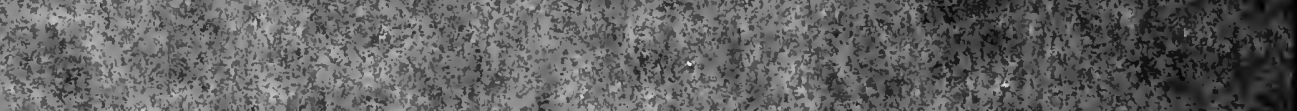
12
$H$

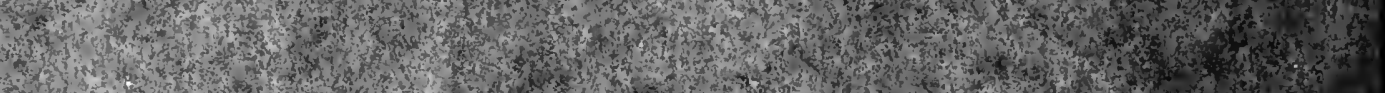

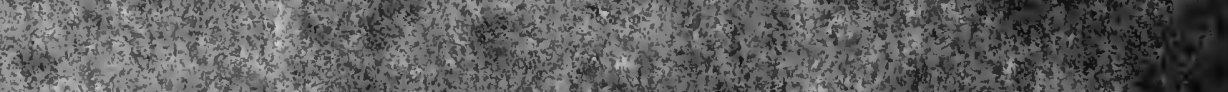

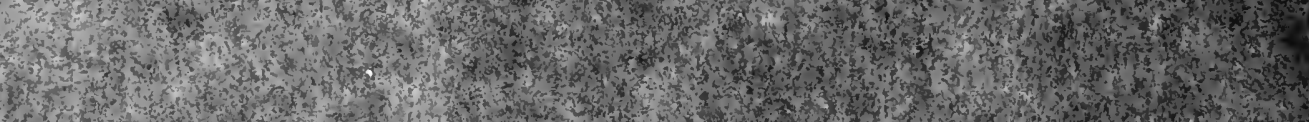
1.

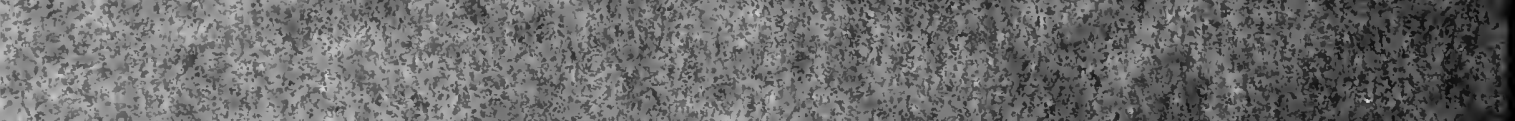

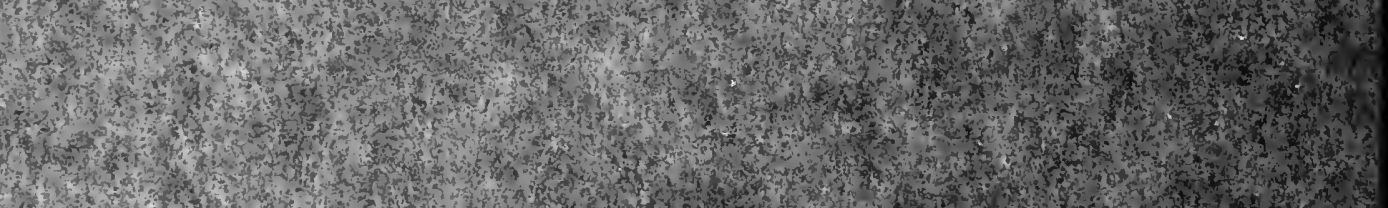
13
1

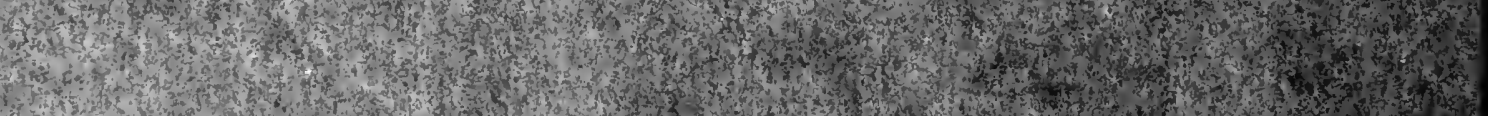
3
7

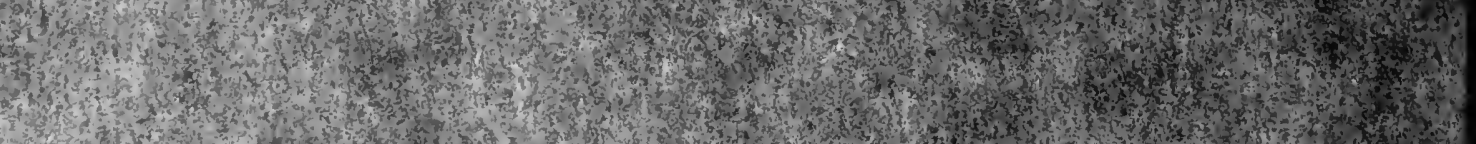

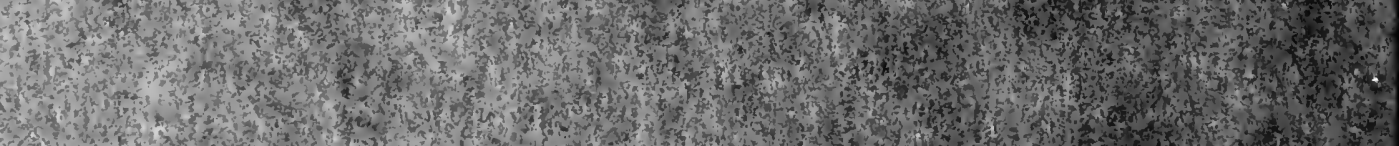

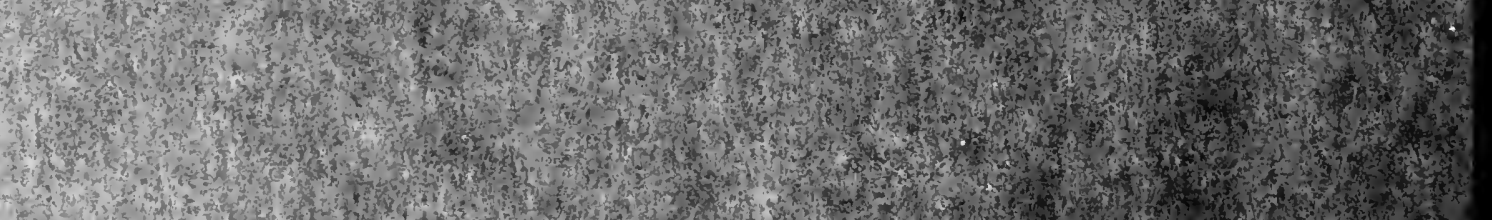
3
7

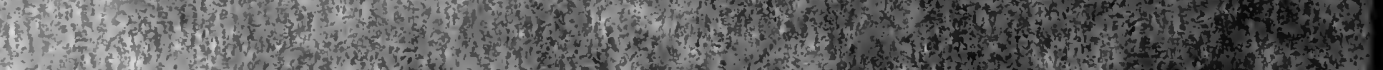

